\title{
Biodiversity Economy and conservation territorialization: a pyrrhic strategy in Kwazulu-Natal
}

\author{
Adrian $\mathrm{Nel}^{1}$ \\ University of Kwazulu-Natal, South Africa
}

\begin{abstract}
Post-apartheid Kwazulu-Natal is in the midst of ecological and social crises related to land ownership, resource control, minerals extraction, environmental degradation and biodiversity loss. The environs of the HluhluweImfolozi National Park are a violent environment, where the immediate violence of a poaching and antipoaching 'war' waged over fears of Rhinoceros extinction, is counter-posed to the slow violence permeating the lives of marginal rural residents affected by the externalities of coal mining. A range of struggles are waged against these challenges, but a hegemonic 'Biodiversity Economy' intervention has arisen, attended by projects aimed at territorializing conservation space and multiple-win scenarios. Based on four years of intermittent research in the area, this article critiques the territorialization of conservation, project outcomes, and commercialization efforts within the Umfozi Biodiversity Economy Node (UBEN). I contend that a biodiversity economy nodal approach extends neoliberal conservation strategies, and functions as a spatial aggregator to reterritorialize conservation land use over space and time. However, the findings suggest that, despite years of energy and investment there have only been limited individual successes in the UBEN, and a range of frustrations, compounded by COVID-19 complications. The analysis also highlights further costs and externalities of the initiative: as the UBEN exacerbates underlying tensions in Kwazulu-Natal's uneven conservation geography, and it aligns with problematic and often unrepresentative traditional authority structures and related accumulation networks. It is also complicit with the production of sacrificial spaces at the conservation-extraction nexus. In this context, I argue the UBEN is pyrrhic; that is, an outcome or goal strived for/achieved at too little reward and too high a cost. The article extends political-ecological critique of neoliberal conservation and the green economy to incorporate the framing and implementation of biodiversity economy nodal approaches - and their uneven and pyrrhic effects - in contested, crisis-ridden conservation contexts.
\end{abstract}

Keywords: Crisis conservation, biodiversity economy, territorialization, Pyrrhic intervention, sacrifice

\section{Résumé}

Le Kwazulu-Natal post-apartheid est au milieu de crises écologiques et sociales liées à la propriété foncière, au contrôle des ressources, à l'extraction de minéraux, à la dégradation de l'environnement et à la perte de biodiversité. En son sein, les environs du parc national de Hluhluwe-Imfolozi sont un environnement violent, où la violence immédiate d'une " guerre » contre le braconnage est menée par crainte de l'extinction des rhinocéros. Il y a aussi la lente violence qui imprègne la vie des résidents ruraux marginaux touchés par les externalités de l'extraction du charbon. Une série de luttes sont menées contre ces défis, mais une intervention hégémonique "Économie de la biodiversité » a vu le jour, accompagnée de projets visant à territorialiser l'espace de conservation et des scénarios à gains multiples. Sur la base de quatre années de recherche intermittente dans la région, cet article critique la territorialisation de la conservation, les résultats du projet et les efforts de commercialisation au sein du Umfozi Biodiversity Economy Node (UBEN). Je soutiens qu'une approche nodale de l'économie de la biodiversité étend les stratégies de conservation néolibérales et fonctionne comme un agrégateur spatial pour reterritorialiser l'utilisation des terres de conservation dans l'espace et le temps. Cependant, les résultats suggèrent que, malgré des années d'énergie et d'investissement, il n'y a eu que

\footnotetext{
${ }^{1}$ Dr. Adrian Nel, Senior Lecturer in Geography, School of Agricultural, Earth and Environmental Science, University of Kwazulu-Natal, South Africa. Email: nela "at" ukzn.ac.za. Acknowledgements: The author would like to sincerely acknowledge Ezemvelo Kwazulu-Natal Wildlife for authorizing the research project, and both Ezemvelo officials and conservation practitioners for the candid responses. Thank you to Bram Büscher, the other contributors to the Special Issue, and to the reviewers for constructive inputs to the article. This is the third article in Bram Büscher (ed.). 2021. "Political ecologies of extinction", Special Section of the Journal of Political Ecology 28: 696-888.
} 
des succès individuels limités dans l'UBEN, et une série de frustrations, aggravées par les complications du COVID-19. L'analyse met également en évidence les coûts et les externalités supplémentaires de l'initiative : comme l'UBEN exacerbe les tensions sous-jacentes dans la géographie de conservation inégale du KwazuluNatal, il s'aligne sur les structures d'autorité traditionnelles problématiques et souvent non représentatives et les réseaux d'accumulation connexes. Il est également complice de la production d'espaces sacrificiels au niveau du lien conservation-extraction. Dans ce contexte, je soutiens que l'UBEN est comme Pyrrhus ; c'est-à-dire un résultat ou un objectif recherché/atteint avec trop peu de récompense et un coût trop élevé. L'article étend la critique politico-écologique de la conservation néolibérale et de l'économie verte. il intègre également le cadrage et la mise en œuvre d'approches nodales de l'économie de la biodiversité - et leurs effets inégaux et pyrrhiques - dans des contextes de conservation contestés et en crise.

Mots clés: Conservation de crise, économie de la biodiversité, territorialisation, intervention à la Pyrrhus, sacrifice

\section{Resumen}

Kwazulu-Natal, en la Sudáfrica posterior al apartheid, está inmersa en una crisis ecológica y social relacionada con la propiedad de la tierra, el control de los recursos, la extracción de minerales, la degradación del medio ambiente y la pérdida de biodiversidad. Alrededor del Parque Nacional de Hluhluwe-Imfolozi tiene lugar una violenta "guerra" contra la caza furtiva y la extinción del rinoceronte. Además, las externalidades de la minería del carbón crean una forma de "violencia lenta" que afecta a la vida de los residentes rurales marginales. Contra estos desafíos se libra una serie de luchas. También ha surgido una "Economía de la Biodiversidad" hegemónica, que consiste en proyectos para territorializar la conservación de la vida silvestre. Basándose en cuatro años de investigación intermitente en la zona, este artículo critica la territorialización de la conservación, los resultados de los proyectos y los esfuerzos de comercialización dentro del Nodo de Economía de la Biodiversidad de Umfozi (UBEN). Sostengo que el "enfoque nodal" de la economía de la biodiversidad es una estrategia de conservación neoliberal. Funciona como un agregador espacial para reterritorializar el uso del suelo de conservación, extendiéndolo en el espacio y el tiempo. Sin embargo, a pesar de los años de energía e inversión, los éxitos individuales en la UBEN han sido limitados y se han producido una serie de frustraciones, agravadas por las complicaciones de COVID-19. La UBEN exacerba las tensiones subyacentes en la desigual geografía de la conservación de Kwazulu-Natal, y se alinea con estructuras de autoridad tradicionales problemáticas y a menudo poco representativas y con las redes de acumulación relacionadas. También produce espacios de sacrificio en el nexo de la conservación y la extracción. Sostengo que la UBEN es pírrica; se esfuerza por alcanzar objetivos, pero éstos se están logrando con muy poca recompensa y a un alto coste. El artículo amplía la crítica político-ecológica a la conservación neoliberal y a la economía verde, para incorporar la implementación de una "economía de la biodiversidad" nodal en este contexto de conservación impugnado y en crisis.

Palabras clave: Conservación en crisis, economía de la biodiversidad, territorialización, intervención pírrica, sacrificio

\section{Introduction: conservation, conflict and the Biodiversity Economy}

Political ecology has been particularly adept at exploring the discourses, policy prescriptions and institutionalized interventions of programs to tackle global environmental problems, and the outcomes of these programs (Adger et al., 2001). They can be distanced from local resource users and local dynamics (Adger et al., 2001, 681). For example, 'green grabbing' can arise where resource access and uses are altered by 'green economy' interventions (Corson et al. 2013). Their credentialing and operation can justify 'accumulation by dispossession' or alter patterns of institutional arrangements, authority and rules (Sikor and Lund, 2009). For Adams and Mulligan $(2003,11)$, biodiversity management initiatives, one aspect of the green economy, are potentially a "colonial expropriation of nature in a new guise", which reify racialized access and dispossession patterns (Magome and Murombedzi, 2003; Wolmer, 2004: 314). In this vein, critique of the neoliberalization of nature and neoliberal conservation has been a focus of political-ecological enquiry (McCarthy and Prudham, 2004, Büscher et al., 2011), to understand the social dynamics of the production of space and nature (Smith, 2010). Of particular focus are 'crisis conservation' interventions, where 'green wars' are fought to safeguard species and ecosystems from degradation and extinction (Büscher et al., 2017; Marijnen and Verweijen, 2016). While there is an extensive critique of neoliberal conservation and the green economy within political ecology, 
there is less focus on the 'biodiversity economy.' This is because, in practice, the biodiversity economy is less favoured as a framing concept. Nonetheless it is extensively adopted in rhetoric and in practice in South Africa, and worthy of investigation for the novelties it exhibits when deployed in the territorialization of conservation initiatives.

South Africa, the world's third most biodiverse country, faces funding crises, biodiversity loss through land use change, and extinction crises for both flora and (mega)fauna. ${ }^{2}$ There is a contested debate about the access to, use of and funding for protected areas for conservation in a postcolonial context (Carnie, 2017; Gewald et al., 2019; SANBI, 2010). Conservation landscapes in South Africa are also power-laden, with the interplay of territory, wealth, commodification and often violent strategies for barring access to marginalized residents (Beinart and Coates, 1995; Ramutsindela and Büscher, 2019; Gewald et al., 2020). In this context of ongoing crisis, wildlife and conservation has been subject to new and existing actors with vested interests in transforming conservation landscapes, particularly ecotourism capital. Consistent with an increasing interweaving between conservation and (neoliberal) capitalist policies and values (Brockington et al., 2008, 3), and in part as a response to multi-faceted local crises, a National Biodiversity Economic Development Strategy (NBEDS) has coalesced in South Africa. Its purpose is to value ecosystem services and to commercialise and trade in the countries' biodiversity and its components (DEA, 2014). The 'Greater uMfolozi Biodiversity Economy node' (UBEN) is one such spatial intervention in northern Kwazulu-Natal. Using this example, the article questions the outcomes and effects of the biodiversity economy as an entry point for conservation reterritorialization. It also extends the critique of neoliberal conservation in political ecology.

The article draws from key informant interviews and field visits conducted from 2016 to 2020 after development occurred in the UBEN. Research engagement included interviews conducted with various stakeholders, including Azevedo officials ranging from park managers, game rangers, resort managers and current and former Community Conservation Officers. I also interviewed an official from the S.A. Hunters Association; developers of ecotourism initiatives within the biodiversity economy node; and finally, Amakhosi, land claimants, and residents adjacent to conservation areas.

The UBEN is conceptualized as a neoliberal crisis response and commodification strategy which functions as a 'spatial aggregator' to facilitate and amalgamate discrete projects and reterritorialize conservation land use across the landscape. It also acts as a proto-territory to extend conservation territorialization, the financialization of conservation space, and the commodification of wildlife. The findings indicate that despite years of energy and investment, there have only been limited individual successes within the UBEN, and a range of frustrations for many actors, with COVID-19 complications undermining some of the gains even further. Furthermore, the UBEN as an inherent spatial strategy elides underlying tensions in Kwazulu-Natal's uneven conservation geography, exacerbates tensions and enmity in the landscape, and is complicit with the production of sacrificial spaces at the conservation-extraction nexus. Thus the article substantiates two levels of critique, first encapsulated within the concept of the pyrrhic. That is to say the initiative is realized at too little reward, for too much effort and at too great a cost. The article's second broader conclusion and contribution to the literature suggest that the biodiversity economy represents the deepening of neoliberal conservation and extension of green economy logic - both institutionally and territorially - in the present and into the future.

\section{Neoliberal conservation and biodiversity economy}

Conservation efforts and initiatives are littered with initiatives that have fallen short of their intended outcomes or failed to stand the test of time (Redford et al., 2013). Contributions in development studies have detailed how rhetoric and well-intentioned interventionism can fall short because of underlying contradictions in the messy reality of local contexts (Li, 2007; Easterly, 2002; Mwenda and Tengri, 2005). Perceptions of selfevident benefits obfuscate the systemic political economy and ecology underpinning the 'problems' they delimit and can close debate on the legitimacy of interventions and their unequal implications and distributive effects

\footnotetext{
${ }^{2}$ Major threats to the Kwazulu-Natal flora are identified in terms of the significant number of plant taxa Red-Listed as threatened with extinction - see http://redlist.sanbi.org/stats.php\#Provincial\%20statistics. While fauna such as Vultures, and most prominently Rhinoceros are recognized to be in an extinction crisis - see http://www.projectrhinokzn.org/aboutus/.
} 
(Ferguson, 2004; Li, 2007). There is also a range of studies that critique the 'pyrrhic' nature of intervention which is to say it is achieved for too little reward or too great a cost (Gould and Lewis, 2016). This is similar to familiar political ecology critiques, of, for example, self-defeating deforestation narratives (Leach and Fairhead, 2000) or problematic green militarization efforts (Duffy, 2014). These examples attune us to the need to cast a critical eye at interventions and environmental crisis responses, even if they are well-intentioned, to gain a more holistic and balanced perspective on their outcomes and implications. This is especially important in the context of the high stakes of contemporary conservation crisis of extinction and biodiversity loss (Büscher, 2013), where responses and plans may have "widespread negative consequences for human populations even as they fail to meet their conservation objectives" (Büscher et al., 2017, 407).

There is well-established theorisation and critique in political ecology of neoliberal conservation (Büscher et al., 2011, Brockington et al., 2008), neoliberal natures (McCarthy and Prudham, 2004) and the green economy (Fairhead et al., 2012, Corson et al., 2010). In northern Kwazulu-Natal, studies have drawn on conceptions of production of space and nature (Smith, 2010) to consider spatial conflicts over the appropriation of conservation space in the Isimangaliso Wetlands Park (Hansen, 2013), while prominent attention has been given to the spatiality of 'transboundary conservation' (Büscher, 2010; Brockington et al., 2008; Ramutsindela, 2004; Wolmer, 2003). These and other sources suggest that contemporary interventions are increasingly directed by forms of green market logic, which have sought to extend market mechanisms to the governance of nature and environmental goods and services (Castree, 2008). Such interventions are built on the premise that natures can only be 'saved' through selling them and through capitalism's expansion (Büscher et al., 2012, 4). The result, as Brockington et al. $(2008,4)$ put it, is that "conservation and capitalism are allying mutually to reshape the world." For Moore (2015), this intensification and extensification (across space) of capitalism has disrupted the metabolism of ecological processes.

To consider how bioeconomy 'takes place', there are three aspects of political-ecological critique to consider that are pertinent to the uneven geographies of conservation in South Africa. Firstly, conservation territorialization in South Africa has been predicated upon the privilege of the few and the subjectification and marginalization of animals and certain groups of people in society, often in the interests of capital (Beinart and Coates 1995; Ramutsindela, 2004; Carruthers, 2008; Gewald et al., 2019). Secondly, conservation and extraction can increase enmity in rural landscapes and align with problematic and often unrepresentative traditional authority structures and accumulation networks (Ntsebeza, 2005). Mare (2020) has highlighted the dangers of tradition and traditional authority as a type of formal, structured politics, which enriches a narrowly elite minority while overriding democratic rights, effecting a 'state of exception' for the governance of millions of rural residents on customary land who are rendered as 'subjects.' When decisions about conservation territorialization implicate communal land and livelihoods, these networks are decisive. Finally, conservation interventions themselves might facilitate incidences of sacrificial spaces and spaces of exception, which include violence. This has been evident in the militarization of anti-poaching in response to the 'Rhino crisis' in South Africa (Duffy, 2014; Masse and Lunstrum, 2016), where it is clear that the scale and nature of crises and their responses can facilitate antagonistic and violent biopolitics.

In this uneven terrain, I conceptualize what came to be called 'bioeconomy' at the intersection between green economy and neoliberal conservation. Bioeconomy was initially conceptualized by Georgescu-Roegen (1977) to encompass better the biological origin of economic processes (Biber-Freudenberger et al., 2020). In the social sciences, this relation has been well developed - where for instance, Harvey (2003) has argued that cities are the product of 'metabolic circulations' of capital and nature. In practice, there is ongoing scholarly and political discourse on bioeconomy (Biber-Freudenberger et al., 2018), what it should effectively look like (Bugge et al., 2016), or what type of society it would sustain (Hausknost et al., 2017). However, its use is associated with widespread, idealized and expert-led visions and policies of 'green growth' and biotechnology development (Sanz-Hernández et al., 2019). Accordingly, the operationalization of bioeconomy has led to 'weak sustainability' outcomes and frameworks, where economic dimensions prevail over environmental ones (Devaney and Henchion, 2017; Puentes-Rodriguez et al., 2016). Bioeconomy, then, is a contested concept. It aligns with the key characteristics of a boundary object (Devaney and Henchion, 2017) in serving specific interests of different stakeholders as a generally accepted conceptual umbrella (Hodge et al., 2017) and as such there is slippage between what constitutes a biodiversity economy and a green economy. In political ecology 
critique, 'green economy', and the 'economy of repair' (Fairhead et al., 2012) are seen as transformations of the discourse of global ecology and a recasting of environmental problems to accommodate an ontology of natural capital and biodiversity economy, considered a hijacking of its original intent (Birch, 2006). Drawing on these insights, I conceptualize contemporary biodiversity economy as a spatial aggregator to reterritorialize conservation land use across these spaces, extending logics of capital accumulation and commodification across space and into the future.

From a political ecology perspective, the bioeconomy in South Africa appears to be more than an overarching strategy for growth through natural capital exploitation, bioprospecting and wildlife commodification. With regards to the latter, the South African National Biodiversity Economy Strategy (NBAS) is an endeavour to "transfer the entire wildlife sector into a broader economy across the agricultural, ecotourism and conservation domains" (DEA, 2016, 18). To do so, the NBES adopts an inherently spatial approach, intended to rework the conservation footprint and augment the expanding wildlife industry market (growing at 14\% per annum; DEA, 2016) across a range of nodes. It purports to do so through job creation and the restoration and development of 2 million ha of communal land for commercial game ranching (with 300,000 head of game under private/community ownership), wildlife sales, bioprospecting, ecotourism, high-end luxury tourism and heritage tourism, and infrastructure development (DEA, 2014). In adopting a nodal approach, the NBES extends earlier phases of conservation territorialization that have been explored in the literature and which involved the private sector, private landowners and traditional authorities into expanded, postcolonial Protected Area networks. These include the incorporation and consolidation of buffer zones, 'conservation corridors', private nature reserves and game farms, and adjacent communal land (Beinart and Coates 1995; Brandt and Spierenburg, 2014; Spierenburg and Brooks, 2014; Kamuti, 2014; Ngubane and Brooks, 2013). Recent conservation territory expansion initiatives like the Biodiversity Stewardship program (Cockburn et al., 2019; Wright et al., 2018), and Other Effective Conservation Measures (OECMs), are also part of bioeconomy nodal development. Before turning to the UBEN in particular, however, I present the interactions between crisis, neoliberalization and conservation dynamics in the institutional and land use context of Kwazulu-Natal.

\section{Neoliberalization, crisis and conservation dynamics in northern Kwazulu-Natal}

To understand the context within which the UBEN operates, conservation dynamics in KZN must be attended to, since contextual factors and crises have intertwined and contributed to neoliberalizing trajectories. The connections between crises and variegated processes of neoliberalization are well established (Klein, 2007), where capitalist restructurings can both precede and respond to environmental degradation. In Kwazulu-Natal, there has been alignment between neoliberalization and crises in land and politics, institutional changes within Ezemvelo KwaZulu-Natal Wildlife (henceforth Ezemvelo), and broader natural capital utilization through the biodiversity economy and extractives. These have precipitated new conservation territorialization through biodiversity stewardship and biodiversity economy nodal approaches.

Firstly, land and land politics feature prominently in uncertainty over conservation and are pertinent to conservation territorialization. The land dispensation in KZN was conditioned by a legacy of spatial segregation, premised on 'separate development', indirect rule and migrant labor (Guy 1979). Tribal lands created in terms of the controversial Bantu Authorities Act of 1951 - separating colonial Natal from 'communal' Zululand - are now controlled by the Ingonyama Trust ${ }^{3}$, but the land is owned collectively and exhibits dual governance at the local level by municipal councilors, as well as headmen, izinduna (chiefs) and Amakhosi (kings). Recent legislative changes have further entrenched the authoritarian power of traditional authorities and 'investment and development structures', effectively turning residents into "tenants and undermining use rights" (Claasens and Cousins, 2008). On private land, land restitution and redistribution have been pillars of South Africa's land reform program, ostensibly set to address the injustices of the past and transform the structural basis of racial inequality. Land reform, however, has increased uncertainty over land use change, as redistribution has been extremely slow, lacking in political will, and exhibited a shift from pro-poor to neoliberal approaches focused on business development and top-down central administration (Kepe et al., 2005; Hall and

\footnotetext{
${ }^{3}$ Land is held in trust for the people of the former homeland area, and the Zulu King is the sole trustee.
} 
Williams, 2001). Restitution in game parks and private game farms under land claims have also redrawn relationships (Walker, 2008; Kepe et al., 2005), facilitated by creating Communal Property Associations (CPA) and Trusts resulting in community ownership/co-management agreements. The intention is to foster ecotourism or other developments for communal benefit. Still, arrangements are often contested, externally between claimants and other stakeholders, and internally between committee members and beneficiaries (Mtimkhulu and $\mathrm{Nel}$, forthcoming). On unclaimed private land, agricultural land conversions to game farming have allowed the expansion of the wildlife industry over vast stretches of land. Still, they have often been at the detriment of farmworkers, and farm dweller's access to land (Spierenburg and Brooks, 2013; Brandt and Spierenburg, 2014). Thus, in all aspects of the land dispensation, ongoing challenges constitute a crisis of legitimacy and transformation, which directly impact conservation territorialization.

A second dynamic relates to changes at Ezemvelo KwaZulu-Natal Wildife (Ezemvelo), the provincial conservation parastatal, from leadership and funding crises to crisis responses that include a new focus on commercialization and conservation territorialization initiatives. Significant government funding cuts precipitated a financial crisis (Carnie, 2020a) which led to capacity shortages, retrenchments and underfunding of protected areas, all in an increasingly politicized context. According to an anonymous Ezemvelo official, "There was internal political and financial turmoil, funding became political, and Ezemvelo was decimated in terms of personnel, and biodiversity stewardship suffered" (Interview, Hilton, June 2019). In response to this crisis, there has been an increased focus on commercialization, commodification and "sustainable yield" (Interview, Conservations Outcomes Consultant, October 2018). As the Ezemvelo UBEN coordinator put it, "government sees an opportunity when Ezemvelo is running out of resources - moving conservation beyond sanctuaries and notable zones" (Interview, Durban, April 2019). The intent is to attract new partners and generate new revenue for the entity (Sunday Tribune, 2018; Carnie, 2017) and to 'fill the gap' for faltering biodiversity conservation functions (Interview, Conservations Outcomes Consultant, October 2018).

As a specific vehicle to achieve these aims, biodiversity stewardship agreements (BSAs) and associated ecotourism ventures have been described as the most important conservation project in the country and "hugely successful in enacting flexible, protected areas" (Interview, Conservations Outcomes Consultant, October 2018). This situation echoes findings elsewhere, where resource and capacity shortages mean conservationists and managers are increasingly thinking about economic sustainability and long term viability of conservation, and protected nature comes to be seen as a commodity to be sold (McCarthy and Prudham, 2004; Vaccaro et al., 2013). However, the provincial Standing Committee on Public Accounts (SCOPA) has criticized Ezemvelo's focus on commercialization initiatives for their potential to "benefit a select few and exclude the majority of the community and as transgressing their conservation mandate" (News 24, 2020). A leadership crisis has compounded matters, where the leadership, and Board, were removed after various allegations of irregular expenditure, maladministration and political appointments for loyalists to the former president Jacob Zuma between 2009 and 2018 (Carnie, 2020a, 2020b). To complicate matters further, and despite some provincial emergency funding, Ezemvelo and other conservation bodies and organizations dependent on tourism income were hard hit during the COVID-19 lockdown (Stoddard, 2020; Mohamed, 2020).

In parallel to institutional changes and commercializing trajectory within Ezemvelo described above, there has been an increased focus on natural capital utilization - through the 'biodiversity economy' and extractives, at the conservation-extraction nexus. The wildlife sector has seen significant recent efforts and commercialization and commodification of wildlife, despite criticism at the national level for its bias and evasion of calls to shut down or better regulate the industry (Pinnock, 2019). There has been a parallel intensification of the conservation-extraction nexus in Northern Kwazulu-Natal. This has occurred around illeminite and coal extraction (including on the border of the Hluhluwe-Imfolozi Park (Leonard, 2020) and offshore mining, through private investments and state-led programs for economic development (see Walker, 2008; Aardenburg and Nel, 2019). The results of this intensification are detrimental to conservation efforts, and conservationists are often fatalistic. As a local environmental consultant put it, "there is a weak- spined approach to mining by government and a weak EIA process, in which the Department of Mineral Resources is the permitting authority but also the applicant" (Interview, Pietermaritzburg, November 2019). Counter-intuitively perhaps, the relationship between conservation and mining sees an increasing degree of alignment, as is recognized elsewhere (Le Billon, 2021). In this context, conservation actors face difficulties, both politically 
and practically, lobbying against mining development at local and national levels (Interview, Ezemvelo planning officer, Pietermaritzburg, April 2019). Specifically, the conservation-extraction nexus in South Africa is facilitated through Operation Phakisa (Hurry up) - a Presidential initiative to tap into natural resources for economic benefit and job creation that is predominantly focused on offshore mining. However, the biodiversity economy also falls under this initiative, including the proliferation of marine and terrestrial protected areas within its nodes. The trends and dynamics in this Section underpin, support and facilitate biodiversity economy node territorialization, institutionalization, and project implementation, to which I turn to next.

\section{Win-win, crisis response and conservation reterritorialization through the uMfolozi Biodiversity Economy Node}

The Greater uMfolozi Biodiversity Economy Node (UBEN, Figure 1) is promoted an innovative 'winwin' strategy to unlock economic, social and environmental objectives (see Svarstad and Benjaminsen, 2017 for other examples of win-win narratives). It is a nodal intervention to incorporate private land, communal areas, restituted commercial farmland and existing protected areas into an expanded conservation footprint (SAHGCA, 2015). The UBEN was developed by proponents within the S.A. Hunters Association (SAHGCA) and Ezemvelo, who adopted the idea of geographical nodal development from the mining sector (SAHGCA official, Interview, August 2017). In setting out the intervention context for the UBEN, developers assert that they need to be experimental as "currently the Department of Environmental Affairs (DEA) report on biodiversity targets, not economic targets, and within that, we can't show impact" (idem). The UBEN also represents a defensive strategy to stave off risks associated with land use change and land reform, mining, rhino losses through poaching, and pressures from ribbon development following road infrastructure upgrades. Specific mention is made in UBEN documentation of shared risk between parties (SAHGCA, 2015), and commercial risk reduction in the prioritization of viable land for the wildlife economy, while partnerships with community trusts or communal property associations are made in order to "take the risk out of the position" (Interview, Mtonjaneni, November 2018). In this sense, the node is as much a crisis response as the neoliberal institutional changes described above.

The perceived imperative to leverage biodiversity resources for profit, and the benefits of risk reduction, has translated into alliances between private capital and willing traditional authorities or land claim settlement trustees, incorporating communal or restituted lands into an expanded conservation complex. According to respondents, initiatives such as Babanango, the IB5, and Mpembeni are attractive to investors because of significant potential returns without having to purchase land or infrastructure. This facilitates the entry of a new scale of dedicated ecotourism capital investment into ecotourism with better investment, board structures and homogenized management processes, all in a context where land ownership would otherwise be far more uncertain (Interview, Project Rhino Team member, Hluhluwe-Imfolozi, November 2017). This is a significant departure from the third generation farmers (such as the mentor involved in the Kwasanguye initiative) who have facilitated agricultural land conversations to game farms (see Kamuti, 2014). While there have been shortcomings of state facilitation of such projects ${ }^{4}$, these changes fit with the call of the Provincial Member of the Executive Committee (MEC) for Finance to "shift conservation from biodiversity conservation to ecotourism." However, enthusiasm on the part of project proponents within the UBEN itself is tempered because "if you want to do conservation properly, you need to do it with the community and inks (the chief) and the way you do it has to be about ownership, respecting their heritage and history" (Interview, Owner, Thula Thula Private Game Reserve, July 2019). This reflection was a 'lesson learnt' after the founder of Thula Thula, the 'elephant whisperer' Lawrence Anthony struggled and failed to navigate the obstacles in the way of establishing similar conservation corridors to Hluhluwe-Imfolozi.

\footnotetext{
${ }^{4}$ The failings of the Department of Environmental Affairs to contribute money to the BEN for fencing, and for training, as well as the stalling of land claim settlements on the part of the Department of Rural Development and Land Affairs have disappointed of all stakeholders.
} 


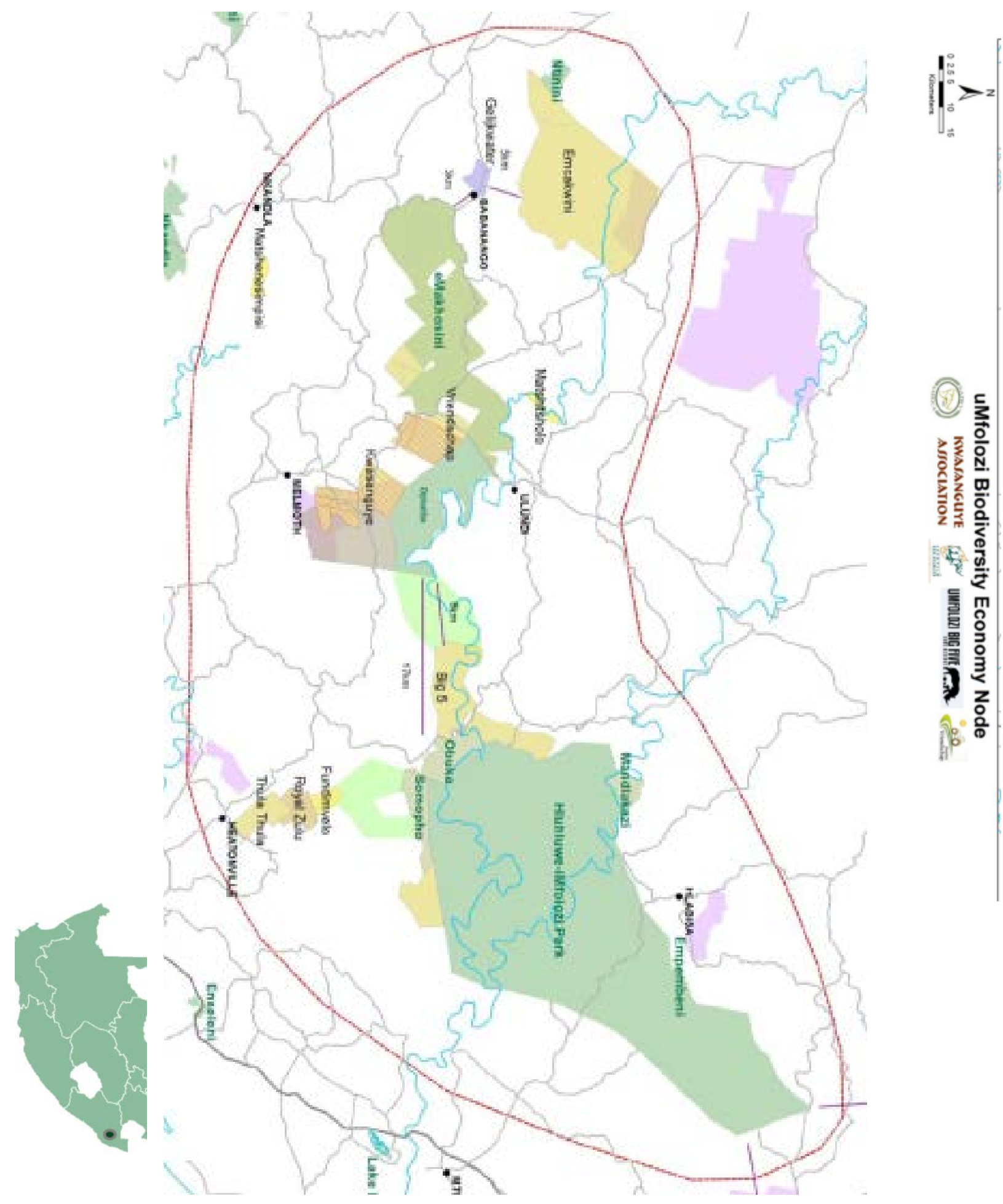

Figure 1: UBEN geography and project locations. Source: SAHGCA 2015. 
The geographical scope of the intervention (Figure 1) is in the environs of Ulundi, including the Hluhluwe-iMfolozi Park (HiP) and prospective eMhakosini-Ophathe Heritage Park (including the 8,825 ha Opathe reserve). Functioning as a spatial aggregator, the target of the UBEN is to consolidate landscape management systems, ecosystems and territories into an extended conservation complex of over 150,000 ha with an improved infrastructure network in "expanding to game reserves, stewardship sites and community reserves around the core conservation parks in the surrounding area" (SAHGCA, 2015: 2). Biodiversity stewardship sites are regarded as vehicles which "give us teeth, [they are] not a pure buffer zone but governed by law after proclamation" (Interview, UBEN coordinator, Durban, 2019). The UBEN also has a spatiotemporal dimension, premised on maximizing the node's commercial value and conservation footprint into the future. Investments in the local Ulundi airport and road infrastructure upgrades are intended to spur future growth in the wildlife and tourism economies of the area, while extension areas and corridor linkages connect the standalone projects and incentivize future expansions. Table 1 below details the UBEN and its constituent project sites, showing a great variety of projects, measures, and multi-partner arrangements in the UBEN that aggregate to maximize a locus of control and potential revenue streams in the present and into the future. In this sense, the UBEN emulates capitalisms' intense focus on future value (Vaccaro et al., 2013) and acts as a 'prototerritory' for future commercialization.

\begin{tabular}{|c|c|c|c|c|}
\hline Size & Landowner & Status & $\begin{array}{l}\text { Management model and } \\
\text { stakeholders }\end{array}$ & Outcomes/ indicative quote \\
\hline \multicolumn{5}{|c|}{ Hluhluwe-Imfolozi Cluster } \\
\hline \multicolumn{5}{|c|}{ 1. Hluhluwe-Imfolozi Park (HIP)Corridor } \\
\hline 2,400 ha & $\begin{array}{l}\text { Resituted land on behalf of } \\
\text { the Corridor of Hope } \\
\text { Trust. Under the Land } \\
\text { Restitution Act land } \\
\text { claimed in protected areas } \\
\text { cannot be restored for } \\
\text { occupation. }\end{array}$ & $\begin{array}{l}\text { Operational but } \\
\text { contested. } \\
\text { Claim settled in } \\
2008 .\end{array}$ & $\begin{array}{l}\text { Co-management structure } \\
\text { between Ezemvelo and } \\
\text { the Corridor of Hope } \\
\text { Trust. The Regional Land } \\
\text { Claims Commission is an } \\
\text { additional stakeholder. }\end{array}$ & $\begin{array}{l}\text { "Everybody's aim is to keep the nature. We need money } \\
\text { and we need to invite people to come and invest." } \\
\text { (Interview, January 2017). } \\
\text { Benefits derive from a percentage of 'gate takings', live } \\
\text { sales of game, bursaries and a community lodge - } \\
\text { Enseleni. Yet, respondents allege some some } 60 \text { million } \\
\text { Rand [approx.. } 3.7 \text { million USD] from the claim has not } \\
\text { been forthcoming, the co-management structure is not } \\
\text { responsive, there are issues with the Trust, and the } \\
\text { community benefit arrangements are perceived as } \\
\text { inadequate. }\end{array}$ \\
\hline \multicolumn{5}{|c|}{ 2. Enseleni Bush Lodge } \\
\hline Approx. 3 ha & $\begin{array}{l}\text { Community lodge within } \\
\text { Protected Area (HiP). }\end{array}$ & Active & $\begin{array}{l}\text { Stakeholders: Ezemvelo } \\
\text { partnership with the } 10 \\
\text { chiefs around HiP. } \\
\text { Ezemvelo run the lodge } \\
\text { on behalf of the } \\
\text { Amakhosi. }\end{array}$ & $\begin{array}{l}\text { The lodge and its benefit model are functional but there } \\
\text { underused budgets, and perception issues: "People think } \\
\text { only Amakhosi benefit - there are funds and we only } \\
\text { advise, lots of money to be used". }\end{array}$ \\
\hline \multicolumn{5}{|c|}{ 3. Mpembeni Rhino Ridge Safari Lodge } \\
\hline 428 ha & $\begin{array}{l}\text { Ingonyama Trust Board } \\
\text { (former communal grazing } \\
\text { land) Esiyembeni } \\
\text { communal land }\end{array}$ & $\begin{array}{l}\text { Active and } \\
\text { operational. }\end{array}$ & $\begin{array}{l}\text { Co-management } \\
\text { Ezemvelo, ITB and } \\
\text { Hlabisa Traditional } \\
\text { Authority }\end{array}$ & $\begin{array}{l}\text { Disbursing benefits and a stable situation where the chief } \\
\text { are trusted and respected. Yet some respondents } \\
\text { indicated that "they could have negotiated better with the } \\
\text { developer and operator," and some community members } \\
\text { indicated they do not see benefits. }\end{array}$ \\
\hline \multicolumn{5}{|c|}{ 4. Somopho (Imfolozi Big 5) } \\
\hline 2,200 ha & $\begin{array}{l}\text { Ingonyama Trust Board } \\
\text { (former communal } \\
\text { grazing). Under the } \\
\text { Somopho traditional } \\
\text { authority, now a Gazetted } \\
\text { game reserve. }\end{array}$ & $\begin{array}{l}\text { Lodge inactive, } \\
\text { but protected areas } \\
\text { gazetted and } \\
\text { incorporated into } \\
\text { HiP; but contested. }\end{array}$ & $\begin{array}{l}\text { Co-management by } \\
\text { Ezemvelo and Somopho } \\
\text { Traditional Authority. } \\
\text { Additional stakeholders: } \\
\text { Inprodev (developer) and } \\
\text { Mantis Collection } \\
\text { (tourism operator). }\end{array}$ & $\begin{array}{l}\text { Mtembu completed } 2019 \text { and was briefly operational } \\
\text { before closure in } 2020 \text {. Initial job creation during the } \\
\text { construction and training for lodge staff and rangers. } \\
\text { Loss of grazing land led to a court challenge to the } \\
\text { gazettement of the reserve. }\end{array}$ \\
\hline \multicolumn{5}{|c|}{ 5. Obuka (Imfolozi Big 5) } \\
\hline 2,496 ha & $\begin{array}{l}\text { Ingonyama Trust Board } \\
\text { (former communal } \\
\text { grazing), now a gazetted } \\
\text { game reserve. }\end{array}$ & $\begin{array}{l}\text { Lodge inactive but } \\
\text { protected areas } \\
\text { gazetted and } \\
\text { incorporated into } \\
\text { HiP. }\end{array}$ & $\begin{array}{l}\text { Co-management } \\
\text { Ezemvelo, ITB, Inprordev } \\
\text { (developer), Obuka } \\
\text { Traditional Authority, }\end{array}$ & $\begin{array}{l}\text { Biyela Lodge completed 2019, but the tourism operator } \\
\text { withdrew in 2020. Some evidence of disgruntlement } \\
\text { amongst a segment of respondents, but less fractious than } \\
\text { the Somopho reserve. The developer is taking the service }\end{array}$ \\
\hline
\end{tabular}




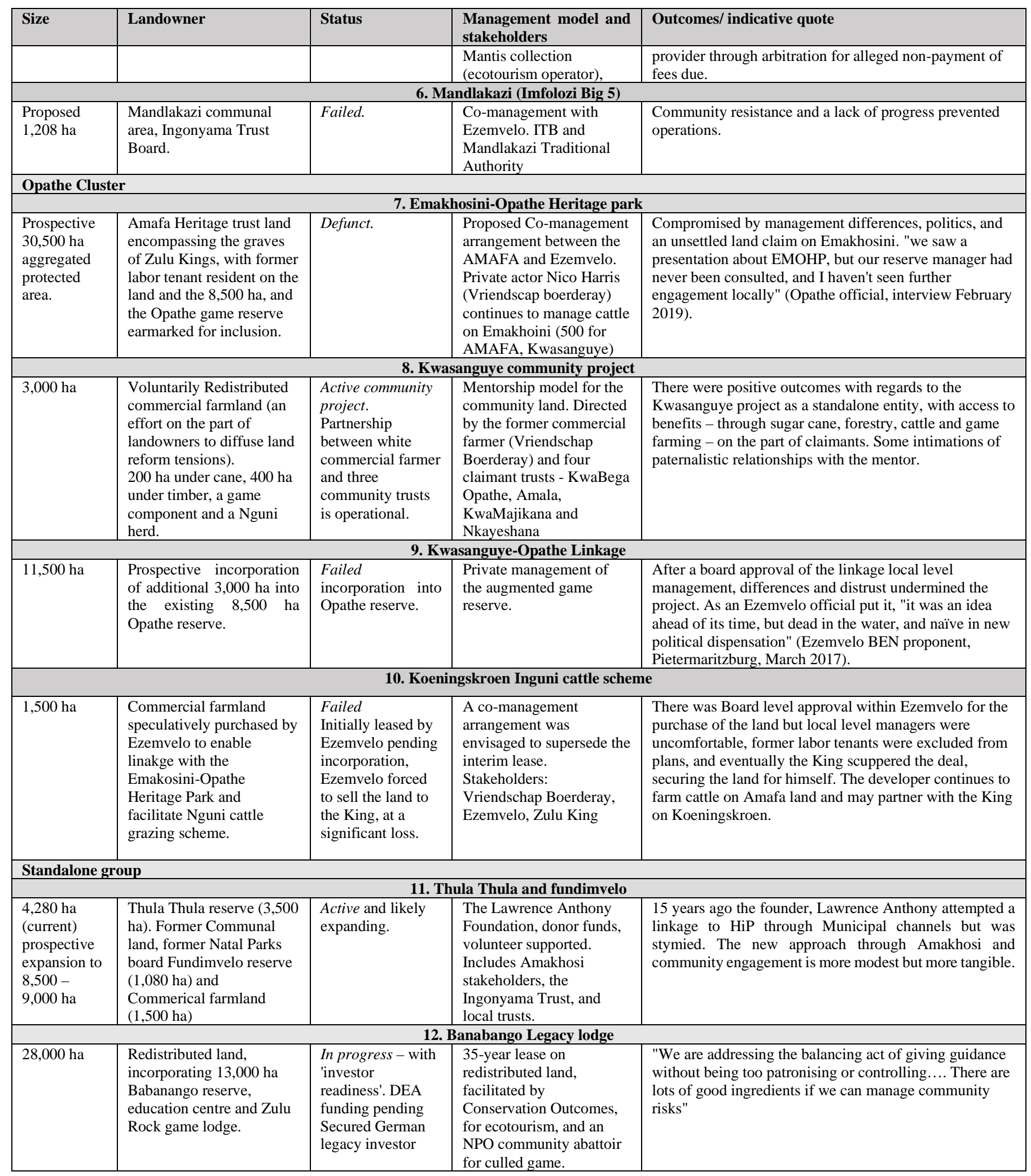

Table 1: List of uBEN project sites in northern KwaZulu-Natal. 
The UBEN developments can be grouped into three - the first two groups involving initiatives that augment the existing Hluhluwe-Imfolozi Park (the HiP Cluster) and Opathe game reserve (the Opathe Cluster). Both core reserves are facing different deterritorialization pressures. HiP experiences issues to do with poaching, fencing problems, human-wildlife conflict and community contestations over benefits and jobs from the park, while Opathe faces illegal grazing, sand mining, hunting with dogs, and underfunding given its low tourist profile (Interviews with Ezemvelo officials 2018 and 2019). The HiP cluster has been more successful with the enclosure of two areas of communal land into the reserve facilitated by traditional authorities under the Imfolozi 'Big 5' project, though the Mandlakzai initiative is defunct after community rejection of the development. The HiP cluster also contains an older conservation expansion area enclosed from communal land. This is the Empembeni Rhino Ridge development, which was facilitated through the 'corridor of hope' land claim settlement and co-management arrangement, though the latter is contested. In contrast to the HiP cluster, the Opathe cluster of projects was unsuccessful in augmenting the Opathe reserve. While the Kwasanguye community conservation initiative alone appears successful to a degree, Opathe's linkages with the adjacent properties of Emakosini, Kwasanguye and Koeningskroen all faltered and failed. The third group, including two standalone 'satellite' projects, at Babanango and Thula, could incorporate into the former two clusters through conservation corridors. They are treading carefully, avoiding commercial hunting and the pitfalls experienced by other projects and trying to foster more community ownership and engagement.

At present, then, three initiatives can be said to be active, two are operational but contested, four are nascent/non-operational, and four are defunct. With this understanding of outcomes in mind, I turn to a discussion of why territorialization through the UBEN might be pyrrhic.

\section{Pyrrhic conservation and the intensification of neoliberal territorialization}

This section draws on experiences in the UBEN to argue that the market triumphalism within the intervention is pyrrhic. Firstly, the project outcomes detailed in Table 1 substantiate that the UBEN may represent too little reward for too much effort. While it remains to be seen if future value in the landscape can be 'unlocked' as its proponents hope, less than a third of projects are active, and fully a third have failed. Given the years of energy and investment that has gone in the UBEN's facilitation, such failures have led to frustrations, as one proponent attests: "co-ordination in the UBEN has been abysmal and caught up in Ezemvelo politics, and if it weren't for Babanango or IB5 there would be nothing to show for it" (Interview, Project proponent, Hilton, 2019). After the interview, even the two IB5 projects faltered when the eco-lodges closed these were the primary income generation vehicle. The ecotourism operator withdrew during the COVID-19 lockdown. Such realities and implementation challenges in Kwazulu-Natal are painfully apparent to actors in this sector, who acknowledge 'few' good examples. Consultants suggest this is because projects in the UBEN are "complex and require long term and in-depth commitment, with community buy-in and real engagement and benefits"; this is a challenge with community conservation and co-management more broadly (see Cock and Fig, 2000). However, I would like to go further in my analysis to suggest further aspects of UBEN's pyrrhic status, achieved at too great a cost. These pertain to the re-enforcement of an uneven conservation geography, the exacerbation of tensions and enmity, and incidences of sacrificial spaces and spaces of exception.

\section{Re-enforcing an uneven conservation geography}

There is a wide range of community benefit models in the UBEN and a range of asymmetries from the point of view of beneficiaries. The literature on neoliberal conservation suggests that projects can frequently widen the distribution of social impacts by interacting with pre-existing economic, social and political inequalities (Holmes and Cavanagh, 2016). This is a significant area of concern given the general context of acute social and economic development needs of the rural poor in the area, many of whom have incurred substantial costs from the establishment of parks but few benefits in return (Gewald et al., 2018). This legacy around the UBEN was pointed out by a former Ezemvelo Community Conservation Officer (CCO): "In Hluhluwe-Imfolozi Park (HiP), there is only one black tourism operator, and he is a ward councillor" (Former CCO, HiP 15 January 2017). This lack of representativity and intractability is fossilized into South African conservation geography (Büscher et al. in press). As the Ezemvelo uBEN coordinator herself put it, "there is a 
lot of gatekeeping when it comes to the financial benefits of conservation - and there is [still] a need to unlock those gates" (Interview, Durban, Feb 2019).

In this context, the benefits from the UBEN are curtailed, generating limited employment opportunities, or community levies from tourist visits to conservation areas, or dividends from ecotourism investments. While investments within the UBEN (such as the IB5) take a long time to mature and pay dividends, as initial loans need to be paid off, community needs are immediate for social reproduction (see Hornby and Cousins, 2019). Perceptions of asymmetric benefits and inequalities can ferment mistrust (Fisher et al., 2019) or re-enforce an already uneven, racialized conservation geography. Even in cases where projects are successful, such as at Mpembeni Rhino Ridge, community beneficiaries can become disillusioned with the benefits accruing (Nsukwini 2019). This arises in a context where some stakeholders feel more robust negotiations with developers might have yielded better outcomes form the different initiatives in the UBEN (Interview, Hilton, November 2018). Two respondents cautioned against private sector developments that have significant power imbalances, or that lack sustained capacity or a financial incentive to manage stakeholder involvement (Interview, Conservation Consultant, October 2018; Interview, Project Rhino Team member, HluhluweImfolozi, November 2017). There are also perceptions that asymmetries exist amongst community respondents in the Hluhluwe-Imfolozi cluster more broadly, who suggest that "Ezemvelo is doing more for Amakhosi (Chiefs), Isilo (the King) and others' benefit... but neglecting the community." (Trust member, Interview, Mtubatuba, June 2019). This view was repeated in the Opathe cluster more broadly, where former labor tenants and land claimants are excluded from benefits within the proposed Emakhosini-Opathe heritage park. As a respondent put it, "projects create expectations but benefits accruing are not what we should have been getting... [and] the real benefit goes to the facilitators" (Emakhosini Claimant, Interview, May 2017). The failed Koeningskroen partnership was particularly controversial. As a consultant in the UBEN put it, "Koeningskroean was another disaster... there was elite capture and traditional politics with the King complicating the process" (Conservation consultant, Interview 2019).

Summing up the community benefit status quo, an Ezemvelo CCO said, "if the community really benefits, we want business owners and partners - in benefits and losses - the pie needs to be split by more people. We don't want a trickle-down" (Interview, 2018). Project proponents in the standalone cluster are wary of the big tourism operations, and developers involved in the other two groups, who they said are "hunting for dollars" and "moving too fast" to ensure genuine participation and benefit-sharing (Interview, Thula Thula, October 2020). This view was also expressed by an Ezemvelo lodge manager in Hip, who was concerned that high-end ecotourism might "hollow out" state resources because Ezemvelo lodges may suffer in competition with new private ones. ${ }^{5}$ One commentator put it that implementers "shouldn't only target the top end, but [should] maximize the value chain and the end of the market to make sure benefits can be distributed more equitably, and ensure biodiversity 'buy-in' (Interview, Project Rhino Team member, Hluhluwe-Imfolozi, November 2017). All of these factors suggest that in its current form, the UBEN might continue to cement an already uneven and 'fossilized' conservation geography (Büscher et al., in press).

\section{Exacerbation of tension and enmity}

When issues of race, participation and exclusion are considered, as well as complex interactions with diverse stakeholders - each with different management approaches, imperatives and priorities - the uBEN can represent a contested landscape for bioeconomy development, and it can exacerbate tension and enmity in the landscape.

For starters, the Hluhluwe-Imfolozi cluster shows that tensions and enmity can arise within heterogenous beneficiary groupings and between residents, traditional authorities and project proponents over new interventions, not least because of the power relations and degree of participation in the planning that precedes them. As one proponent put it, the "biggest risk is the community" (UBEN coordinator, Interview, Durban,

\footnotetext{
${ }^{5}$ The Ezemvelo Mpila camp manager within HiP reflects as much when noting that Mpila lodge and Enseleni (the Amakhosi run lodge) occupancy was down to $70 \%$ in peak seasons and even worse in the slow seasons, yet occupancy is full at the private Rhino Ridge lodge (which also has links to the Empembeni community).
} 
April 2019). In the Somopho traditional area, a group of residents have taken the Inkosi (chief) to court over his support for the gazettement of the protected area as part of the IB5, allegedly without full input into the decisions made (Interviews, Somopho. June 2018, Jan 2019). The consultant offered the following in explanation: "one gets the impression that the project was rushed through and the reserve declared in no time, but there was lots of resistance even within Ezemvelo ... [and] it seems the community hasn't got the best deal" (Interview, Hilton, June 2019). Similar instances are evident over coal mining developments in the area (Leonard 2020). There were lesser complaints in the Obukha area (fieldwork observation, 2019); however, community resistance resulting from development tensions can also be evident, as in the failed initiative of the IB5 Mandlakazi reserve. As an Ezemvelo official put it, "there is no ways the community will allow the project - they are dead set against it" (Interview, January 2020).

In the UBEN, conservation territorialization can exacerbate already fraught relations with core protected areas. Tensions over poor fencing, human-wildlife conflict and anti-poaching efforts are particularly prevalent around HiP (Interview, Ezemvelo Community Conservation Officer, Centenary Centre, November 2018). Existing wildlife policy is contentious as it does not offer compensation for livestock kills by hyena and leopard. ${ }^{6}$ As the chairperson of the local community conservation board attests, "if KZNW doesn't pay for killed goats by hyenas, people might want to kill those predators which they see as their animals because they are land claim beneficiaries" (Interview, Hluhluwe-Imfolozi, November 2017). Tensions over land reform also continue within the node, where the three claims around Kwasanguye and Melmoth remain unsettled, as does a claim at Emakhosini on the part of labor tenants - seen as the least of government's land reform priorities (Hall and Williams, 2001). Violent protests erupt sporadically due to unaddressed issues of human-wildlife conflict and a perceived lack of benefits from conservation, along with tensions over land. In Machibini in 2018, for instance, an Ezemvelo car was torched and tyres burnt on the 618 road to Nyalazi gate of the Umfolozi Park. In another example, the Ezemvelo CCO was held hostage over negotiations to secure more jobs in the Park. When there are such problems and a perceived lack of benefits, then, as a local conservation board ${ }^{7}$ member and Induna put it, "people believe the mine is better [than conservation] as they can show things. Ezemvelo only built 1 school in 100 years and gives 'piece jobs"' (Interview, June 2019).

By contrast, the Opathe cluster shows tensions about management priorities and, to a degree, racial tensions between stakeholders, both of which have undermined project development and connectivity (Interview, Mtonjaneni, November 2018). While Ezemvelo board approval was secured for the EmakhosiniOpathe-Kwasaguye linkage, management tensions and divergences of views about hunting, cattle farming, private management and heritage protection interests prohibited the augmentation of the Opathe cluster. Some UBEN proponents interpret this as "paralysis and archaic views" on the part of Ezemvelo managers. Still, Ezemvelo staff at Opathe expressed significant concerns and frustrations - "if you are planning to drop fences and push to hunt and you don't consult us, it is a problem, how will conservation benefit?" (Interview, Ezemvelo Manager, Opathe June 2019). It is also alleged that the Department of Rural Development and Land Reform (DRDLR) was uncomfortable with a white, former landowner continuing to hold the title deeds for the community-claimed land in Kwasanguye. Similarly, a critical Ezemvelo manager is alleged to have withheld authorization for the initiative because of a perception of a condescending and patriarchal attitude on the part of the same stakeholder. Frustrated by a lack of support, such developments are interpreted by the proponent as unfair, and he has an additional belief that government funding will not be released for the initiative without kickbacks (Interview, Mtonjaneni, November 2018). While the truth of any allegations is beyond the scope of this article, it is clear that racial and organizational tensions are certainly evident in the post-apartheid conservation context of the UBEN. Another Ezemvelo official put it that "our biggest issues are protecting apartheid-era reserves, where there are perceptions of 'white people conservation' and of who should benefit... it is a never-ending transformation issue" (Interview, Pietermaritzburg, February 2019).

\footnotetext{
6 This is because hyena and leopards were said to be a pre-existing feature of the landscape before the creation of the reserve, whereas compensation is paid for lion and wild dog kills as they constitute 're-introduced species' into the park.

${ }^{7}$ A structure set up to mediate people-parks issues in conservation around HiP.
} 


\section{Spaces of exception and sacrifice zones}

As a final point, I detail how spaces of exception and sacrifice operate in a landscape that is directed under a hegemonic economic development paradigm. Northern KZN certainly has spaces of exception when it comes to dispossessions, deprivations and the slow violence associated with coal mining-affected communities (Leonard, 2020). However, conservation territorialization also imposes its burdens on proximate populations within the UBEN. A portion of residents in Somopho traditional authority are opposed to the enclosure of their grazing land, and their Inkosi (chief) was allegedly taking decisions without input (Interviews, Somopho, June 2018, Jan 2019). While this enclosure does not entail dispossession, it does represent the displacement of activities for individuals who engage in multiple livelihood strategies, supported by circular migration for work, livestock rearing and limited subsistence farming and government grants (Nsukwini and Bob, 2016). There is also direct violence associated with poaching and anti-poaching, with costs and losses on both sides of the fence. This is the most obvious example of a space of exception. As the chairperson of KZN's Project Rhino put it: "While this is not a real war, we are acting as a military with a different set of rules" (Interview, HluhluweImfolozi, November 2017). This militarization of conservation exacts physical and psychological costs on rangers and proximate communities, where suspicion and resentment can be rife (Interviews, Hluhluweimfolozi, July 2018). Projects within the UBEN are supportive, and in some cases, facilitative, of the militarization of anti-poaching and do not intervene within human-wildlife conflict situations, though some proponents do sympathize with the plight of adjacent residents. For some of these residents, there remains a perception that "conservation can also be cruel" (Interview, Sangoyane August 2018).

Secondly, there is evidence that sacrificial practices and sacrifice zones (see Bullard, 2000) pertain to the biodiversity economy in KZN; where "the spatial and geographical manifestations of social and environmental damages that are 'written off'" in the national interest and in conservation discourses (Nel, 2016, 247). In facilitating the bioeconomy and territorializing space for high-end ecotourism, externalities are not accounted for in the win-win discourses articulated by proponents (SAGCHA, 2015). In the Hluhluwe-iMfolozi cluster, there are concerns that the commercialization of biodiversity undermines the wilderness ethic famously championed by Ian Player in KZN. For example, some Ezemvelo officials lament that the Umoflozi Wilderness area has been compromised by the presence of the luxury Mtembu and Biyela lodges (Interviews, Feb 2018). Similarly, in Opathe, a key motivation for the augmentation of the reserve and its incorporation with Kwasanguye was to facilitate hunting. Yet local managers had concerns; "if you push to hunt ... how will conservation benefit?" (Interview, Ezemvelo Manager, Opathe June 2019). The second form of sacrifice relates to biodiversity loss outside of protected areas ${ }^{8}$ precipitated by a decreased lack of Ezemvelo intervention in the face of 'poor environmental decision making and political interference' and because of budget cuts and staff shortages. ${ }^{9}$ Such contextual challenges lead to a sense of fatalism for planners, manifesting as a need to work within a neoliberal framework - "if you want to be effective you have to step out of the EIA process towards proactive planning - like offsets or making the economic case for biodiversity" (idem).

Finally, at a national scale, the framing of the biodiversity economy is embedded in power structures that may, in turn, undermine conservation, specifically within the presidential Operation Phakisa. This operation aims at "unlocking the economic potential of South Africa's biodiversity in order to reach a growth target of 5\% per year by 2019" (SONA, 2014). Phakisa has a neoliberal orientation around the fast-tracking of offshore oil and gas development in a one-stop-shop within the Department of Mineral Resources - itself a prodevelopment mining body which has also subsumed environmental authorizations for mining away from the Department of Environmental Affairs. This approach is compatible with the local biodiversity framing over businesses and economic activities that directly depend on biodiversity, including fossil fuels derived from organic matter. While there has been an increase of Marine Protected areas under Phakisa from $0.5 \%$ to 5\%,

\footnotetext{
8 Protected Areas comprise only $9 \%$ of Kwazulu-Natal, while $57 \%$ of the high biodiversity lies outside PAs (SANBI National Biodiversity Assessment 2018)

${ }^{9}$ While Ezemvelo is mandated to scrutinize all developments and Environmental Impact Assessments (EIAs) in the Province, planning staff can only comment on development applications within $2 \mathrm{~km}$ of Protected Areas and in other Critical Biodiversity Areas. Furthermore, an Ezemvelo planner attests they only have the resources to target EIAs, which are 'fatally flawed' to ensure efficiency, lamenting that "put simply, biodiversity is not a priority" (Ezemvelo planner, Pietermaritzburg, August 2018).
} 
the remaining $95 \%$ of South Africa's marine Exclusive Economic Zone is now out for lease. As one EIA practitioner put it, "these little islands [MPAs], which is really all they are, is a result of Phakisa which fast tracks both MPAs and mining.... if mining benefits the Republic as a whole (sic) it outweighs the community and environmental risk, then it will go ahead" (Interview, Pietermaritzburg, Nov 2019). Such a sacrificial, neoliberal development orientation certainly works against plans to mitigate biodiversity loss risks associated with mining. In this and the instances above, then, an assessment of the UBEN as pyrrhic deserves attention.

\section{Conclusion: Biodiversity Economy as an intensification of neoliberal conservation and territorialization}

There has been much enthusiasm for the Biodiversity Economy and its articulation with new conservation territorialization initiatives, such as biodiversity stewardship arrangements (DEA, 2016). There has also been a concurrent degree of planning and effort made by an array of actors to realize a nodal approach to conservation territorialization in the Umfolozi Biodiversity Economy Node. This took place amidst a multifaceted conservation crisis of significant biodiversity loss and extinction, uncertainty over land-use change, institutional crises, rhino poaching, and degradation associated with coal mining. In the article, then, the UBEN is conceptualized as both a neoliberal crisis response and as a commodification strategy, functioning as a spatial aggregator and 'proto-territory' to facilitate and amalgamate discreet projects as well as the financialization of conservation space and the wildlife economy, now and into the future.

The findings also suggested that a nodal approach to biodiversity economy in Kwazulu-Natal might be pyrrhic: too great an effort for too little reward. Firstly, there was a major effort, but few successes, in reaching project goals. At a local level, the aims and intentions of many actors may be well placed, and there are limited successes, as well as patent failures. This aligns with Stoddard's (2020) claims that South Africa's 'experiment in wildlife privatization' is threatened; in the face of COVID and other dynamics, and its focus largely caters to the affluent. Its mounting costs contrast it to other pressing social needs faced by the government (idem).

This point alone questions whether if the Biodiversity Economy initiatives were realized with less effort, and for more reward, then the ends would justify the means. My argument has been that the costs have been too great, and embedded in problematic, historically rooted dynamics. The distributional asymmetries of the biodiversity economy approach question its suitability for mitigating conservation risks from land-use change, land reform, mining and rhino poaching. I argued that the UBEN can reinforce uneven conservation geographies, exacerbate underlying tensions and enmity, and be complicit with the production of sacrificial spaces at the conservation-extraction nexus. Thus, the more profound critique in the article focuses on the costs of a broader spatialization of the extractive economy that involve a deeper embedding of hegemonic neoliberalism, of which the UBEN is a part. In this light, the findings align with Bluwstein and Lund (2018) to suggest that even amidst their significant failures, conflicts and tensions, novel conservation formulations such as those described in this article remain powerful. They are gradually transforming communal and other landscapes into conservation territories.

\section{Bibliography}

Adams, W.M. \& Mulligan, M. (eds.). 2003. Decolonising nature: strategies for conservation in a postcolonial era. Earthscan.

Adger, W., Benjaminsen, T.A., Brown, K. \& Svarstad, H. 2001. Advancing a political ecology of global environmental discourses. Development and Change 32(4): 681-715.

Agamben, G. 1998. Homo sacer: Sovereign power and bare life. Stanford University Press.

Aardenburg, E. \& Nel, A. 2019. Fatalism and dissidence in Dukuduku, KwaZulu-Natal, South Africa: Ongoing contestations over land, resources and identities. Journal of Southern African Studies 45(2): 393-411.

Beinart, W. \& P Coates. 1995. Environment and history: the taming of nature in the USA and South Africa. Routledge.

Biber-Freudenberger, L., Basukala, A., Bruckner, M., \& Börner, J. 2018. Sustainability performance of national bio-economies. Sustainability, 10(8), 2705. https://doi.org/10.3390/su10082705 
Biber-Freudenberger, L., Ergeneman, C., Förster, J.J., Deitz, T., \& Börner, J. 2020. Bioeconomy futures: Expectation patterns of scientists and practitioners on the sustainability of bio-based transformation. Sustainable Development 28(5): 1220-1235. https://doi.org/10.1002/sd.2072

Birch, K. 2006. The neoliberal underpinnings of the bioeconomy: the ideological discourses and practices of economic competitiveness. Genomics, Society and Policy, 2(3): 1-15.

Bluwstein, J. \& Lund, J. F. 2018. Territoriality by conservation in the Selous-Niassa Corridor in Tanzania. World Development 101: 453-465. https://doi.org/10.1016/j.worlddev.2016.09.010

Brandt, F. \& Spierenburg, M. 2014. Game fences in the Karoo: reconfiguring spatial and social relations. Journal of Contemporary African Studies, 32(2): 220-237.

Brockington, D., Duffy, R. \& Igoe, J. 2008. Nature unbound: conservation, capitalism and the future of protected areas. Earthscan.

Bugge, M.M., Hansen, T. \& Klitkou, A., 2016. What is the bioeconomy? A review of the literature. Sustainability 8(7): 691. https://doi.org/10.3390/su8070691

Büscher, B. 2013. Transforming the frontier: Peace Parks and the politics of neoliberal conservation in Southern Africa. Duke University Press.

Büscher, B. 2018. From Biopower to Ontopower? Violent responses to wildlife crime and the new geographies of conservation. Conservation \& Society 16(2): 157-169. http://doi.org/10.4103/cs.cs_16_159

Büscher, B., Fletcher, R., Brockington, D., Sandbrook, C., Adams, W., Campbell, L., . . Shanker, K. (2017). Half-Earth or Whole Earth? Radical ideas for conservation, and their implications. Oryx, 51(3), 407410. http://doi.org/10.1017/S0030605316001228

Büscher, B., Koot, S. \& Thakholi, L. In press. Fossilized conservation, or the unsustainability of saving nature in South Africa. Environmental and Planning E.

Bullard, R., 2000. Environmental Justice in the 21st Century. People of Color environmental groups directory, (pp. 1-21). Environmental Justice Resource Center, Clark Atlanta University.

Castree, N. 2008. Neoliberalising nature: The logics of deregulation and reregulation. Environment and Planning A 40(1): 131-152. https://doi.org/10.1068/3999

Carnie, T. 2017. Tough choices ahead for Kruger National Park. Daily Maverick. 27 June. Available: https://www.dailymaverick.co.za/article/2017-06-27-op-ed-tough-choices-ahead-for-kruger-nationalpark/

Carnie, T. 2020a. KZN's 'sinking conservation ship' hits another storm (Part 1). Daily Maverick 24 August. Available: https://www.dailymaverick.co.za/article/2020-08-24-kzns-sinking-conservation-ship-hitsanother-storm-part-1/

Carnie, T. 2020b. Questions re-appear over costs, staffing levels and politics at KZN's 'sinking ship'

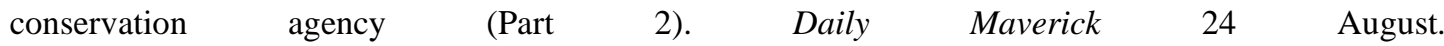
https://www.dailymaverick.co.za/article/2020-08-24-questions-re-appear-over-costs-staffing-levelsand-politics-at-kzns-sinking-ship-conservation-agency-part-2/

Carruthers, J. 2008. Conservation and wildlife management in South African national parks, 1930s-1960s. Journal of the History of Biology, 41(2): 203-236.

Cockburn, J., Cundill, G., Shackleton, S. \& Rouget, M. 2019. The meaning and practice of stewardship in South Africa. South African Journal of Science, 115(5-6): 1-13.

Corson, C., MacDonald, K. \& Neimark, B. 2013. Grabbing "green": Markets, environmental governance and the materialisation of natural capital. Human Geography 6(1): 1-15.

Claassens, A. \& Cousins, B. (eds.). 2008. Land, power and custom: Controversies generated by South Africa's Communal Land Rights Act. Juta and Company Ltd.

CER - https://cer.org.za/news/government-creates-20-new-marine-protected-areas-giving-legal-protection-to5-of-sa-marine-environment 
DEA. 2014. The Biodiversity Economy: South Africa's strategic approach to raising the value proposition of Biodiversity. Presentation by K. Naicker. Department of Environmental Affairs. Available: https://www1.sun.ac.za/awei/sites/default/files/2017-BiodiversityEconomy.pdf

DEA. 2016. National Biodiversity Economy Strategy (NBES). Department of Environmental Affairs.

DEA. 2017. Spatial aspects of the Wildlife Economy. Presented at the Biodiversity Planning Forum, 21 June 2017. Available: http://biodiversityadvisor.sanbi.org/wp-content/uploads/2017/12/1.-Mkefe-Spatialaspects-of-wildlife-economy.pdf

Devaney, L., Henchion, M. \& Á. Regan, A. 2017. Good governance in the bioeconomy. EuroChoices, 16(2): 41-46.

Duffy, R. 2014. Waging a war to save biodiversity: The rise of militarised conservation. International Affairs, 90(4): 819-834.

Easterly, W. 2002. The cartel of good intentions. Foreign Policy, July : 40-49.

Fairhead, J., Leach, M. \& I. Scoones. I. 2012. Green grabbing: a new appropriation of nature? Journal of Peasant Studies 39(2): 237-261.

Ferguson, J., 2006. The anti-politics machine: 'Development', depoliticization and bureaucratic power in Lesotho. Cambridge University Press.

Fisher, J.A., Cavanagh., C., Sikor, T. \& Mwayafu, D. 2018. Linking notions of justice and project outcomes in carbon offset forestry projects: Insights from a comparative study in Uganda. Land Use Policy 73: 259268.

Georgescu-Roegen, N. 1977. Inequality, limits and growth from a bioeconomic viewpoint. Review of Social Economy 35(3): 361-375.

Gewald, J.B., Spierenburg, M. and Wels, H. (eds.). 2018. Nature conservation in Southern Africa. Morality and marginality: Towards sentient conservation? Brill.

Gould, K.A. \& Lewis, T.L., 2016. Green gentrification: Urban sustainability and the struggle for environmental justice. Routledge.

Guy, J. 1979. The destruction of the Zulu Kingdom: The civil war in Zululand, 1879-1884. Addison-Wesley Longman.

Hall, R. \& Williams, G. 2001. Land reform in South Africa: problems and prospects. Centre for Rural Legal Studies.

Hansen, M. 2013. New geographies of conservation and globalisation: The spatiality of development for conservation in the iSimangaliso Wetland Park, South Africa. Journal of Contemporary African Studies 31(3): 481-502.

Harvey, D. 2003. The right to the city. International Journal of Urban and Regional Research, 27(4): 939-941.

Hausknost, D., Schriefl, E., Lauk, C. \& Kalt, G. 2017. A transition to which bioeconomy? An exploration of diverging techno-political choices. Sustainability 9(4): 669. https://doi.org/10.3390/su9040669

Hodge, D., Brukas, V. \& A. Giurca, A. 2017. Forests in a bioeconomy: bridge, boundary or divide? Scandinavian Journal of Forest Research 32(7): 582-587. https://doi.org/10.1080/02827581.2017.1315833

Holmes, G. \& Cavanagh, C. 2016. A review of the social impacts of neoliberal conservation: Formations, inequalities, contestations. Geoforum 75: 199-209.

Hornby, D. \& Cousins, B. "Reproducing the social": contradictory interconnections between land, cattle production and household relations in the Besters Land Reform Project, South Africa. Anthropology Southern Africa, 42(3): 202-216. https://doi.org/10.1080/23323256.2019.1653206

Kamuti, T. 2014. The fractured state in the governance of private game farming: The case of KwaZulu-Natal Province, South Africa. Journal of Contemporary African Studies 32(2): 190-206.

Kepe T., Wynberg, R. \& Ellis, W. 2005. Land reform and biodiversity conservation in South Africa: complementary or in conflict? International Journal of Biodiversity Science \& Management, 1(1): 3-16.

Klein, N. 2007. The shock doctrine: The rise of disaster capitalism. Macmillan. 
Le Billion, P. 2021. Crisis conservation and green extraction: biodiversity offsets as spaces of double exception. Journal of Poltiical Ecology 28(1): xx https://doi.org/10.2458/jpe.2991

Li, T.M., 2007. The will to improve: Governmentality, development, and the practice of politics. Duke University Press.

Leach, M. \& Fairhead, J. 2000. Challenging neo-Malthusian deforestation analyses in West Africa's dynamic forest landscapes. Population and Development Review 26(1): 17-43.

Leonard, L., 2020. Ecological conflicts, resistance, collective action and just resilience: What can we learn from a community struggle against a proposed coalmine in Fuleni, KwaZulu-Natal, South Africa. Politikon https://doi.org/10.1080/02589346.2020.1848756

Maré, G. 2020. Ethnic continuities and a state of exception: Goodwill Zwelithini, Mangosuthu Buthelezi and Jacob Zuma. University of KwaZulu-Natal Press.

Magome, H. \& Murombedzi, J. 2003. Sharing South African national parks: Community land and conservation in a democratic South Africa. In Adams, W.M. and Mulligan, M. (eds.). Decolonising nature: Strategies for conservation in a postcolonial era. (pp. 108-134). Earthscan.

Marijnen, E., \& Verweijen, J. 2016. Selling green militarisation: The discursive (re) production of militarised conservation in the Virunga National Park, Democratic Republic of the Congo. Geoforum, 75, 274-285.

Massé, F. \& E. Lunstrum, E. 2016. Accumulation by securitisation: Commercial poaching, neoliberal conservation, and the creation of new wildlife frontiers. Geoforum 69: 227-237.

Mohamed, S. 2020. National lockdown tightens its grip on game reserves and their staff. Daily Maverick 20 May. Available: https://www.dailymaverick.co.za/article/2020-05-20-national-lockdown-tightens-itsgrip-on-game-reserves-and-their-staff/

Moore, J., 2015. Capitalism in the Web of Life: Ecology and the accumulation of capital. Verso.

Mtimkhulu and Nel forthcoming. Submitted to Political Geography.

Mwenda, A. \& R. Tangri. 2005. Patronage politics, donor reforms, and regime consolidation in Uganda. African Affairs 104(416): 449-467.

Nel, A. 2016. The choreography of sacrifice: Market environmentalism, biopolitics and environmental damage. Geoforum 65: 246-254.

News 24. 2020. Scopa blasts Ezemvelo. Accessed: 21/02/2020. Available: https://m.news24.com/SouthAfrica/News/scopa-blasts-ezemvelo-20200220

Ngubane, M. \& Brooks, S., 2013. Land beneficiaries as game farmers: conservation, land reform and the invention of the 'community game farm' in KwaZulu-Natal. Journal of Contemporary African Studies 31(3): 399-420.

Nsukwini, S. \& Bob, U. 2016. The socio-economic impacts of ecotourism in rural areas: A case study of Nompondo and the Hluhluwe-iMfolozi Park (HiP). African Journal of Hospitality, Tourism and Leisure. 5: $1-15$.

Nsukwini, S. \& Bob, U. 2019. Protected areas, community costs and benefits: A comparative study of selected conservation case studies from Northern Kwazulu-Natal, South Africa. GeoJournal of Tourism and Geosites 27(4): 1377-1391.

Ntsebeza, L. 2005. Democracy compromised: Chiefs and the politics of the land in South Africa. Brill.

Pinnock, D. 2019. 'Expert' panel allegedly weighted to 'duck' Parliament's call to shut down canned hunting. Daily Maverick 25 November. Available: https://www.dailymaverick.co.za/article/2019-11-25-newexpert-panel-may-be-weighted-to-duck-parliaments-call-to-shut-down-canned-hunting/

Puentes-Rodriguez, Y., Ramcilovik-Suominen. S., Torssonen. P., Pitkänen. S. \& Pykäläinen J. 2016. Bioeconomy aspects: Value chain analysis for fuelwood. In Mononen K. \& Pitkänen S. (eds.). Sustainable fuelwood management in West Africa. University of Eastern Finland.

Ramutsindela, M. 2004. Parks and people in postcolonial societies: experiences in southern Africa. Springer. 
Ramutsindela, M. \& Büscher, B., 2019. Environmental governance and the (re-) making of the African state. In N. Cheeseman (ed.). Oxford Encyclopedia of African politics. Oxford University Press. https://doi.org/10.1093/acrefore/9780190228637.013.903

Redford, K. H., Padoch, C. \& Sunderland, T. 2013. Fads, funding, and forgetting in three decades of conservation. Conservation Biology 27(3): 437-438.

SAHGCA. 2015. Umfolozi-Emakhosini-Opathe Biodiversity Economy Initiative. Presentation at the Land Reform and Biodiversity Stewardship Initiative Learning Exchange, 9-12 February 2015.

SANBI. 2010. Ecosystem Profile - Maputaland-Pondoland-Albany Biodiversity Hotspot. Critical Ecosystem Partnership Fund.

SANBI. 2018. National Biodiversity Assessment. Available: http://opus.sanbi.org/jspui/bitstream/20.500.12143/6937/1/NBA\%202018\%20\%20Provincial\%20Summaries\%20of\%20pressures\%2020200318.pdf

Sanz-Hernández, A., Esteban, E. \& Garrido, P. 2019. Transition to a bioeconomy: Perspectives from social sciences. Journal of Cleaner Production 224: 107-119.

Smith, N. (2010). Uneven development: Nature, capital, and the production of space. University of Georgia Press.

Spierenburg, M. \& S. Brooks. 2014. Private game farming and its social consequences in post-apartheid South Africa: Contestations over wildlife, property and agrarian futures. Journal of Contemporary African Studies, 32(2): 151-172.

Sikor, T. \& C. Lund. 2009. Access and property: a question of power and authority. Development and Change, 40(1): $1-22$.

Sunday Tribune, 2018. New Ezemvelo boss plans to revive cash-strapped entity. 15 July. Available: https://www.iol.co.za/sunday-tribune/news/new-ezemvelo-boss-plans-to-revive-cash-strapped-entity$\underline{16033402}$

Stoddard, E. 2020. South African game-farming industry on the 'brink of collapse'. Daily Maverick. 11 May Available: https://www.dailymaverick.co.za/article/2020-05-11-south-african-game-farming-industryon-the-brink-of-collapse/\#

Svarstad, H. \& T.A. Benjaminsen. 2017. Nothing succeeds like success narratives: A case of conservation and development in the time of REDD. Journal of Eastern African Studies 11(3): 482-505.

Vaccaro, I., Beltran, O. \& Paquet, P. A. 2013. Political ecology and conservation policies: Some theoretical genealogies. Journal of Political Ecology 20(1): 255-272. https://doi.org/10.2458/v20i1.21748

Walker, C., 2008. Landmarked: land claims and land restitution in South Africa. Jacana Media/ohio University Press.

Wolmer, W. 2003. Transboundary conservation: the politics of ecological integrity in the Great Limpopo Transfrontier Park. Journal of Southern African Studies 29(1): 261-278.

Wright, D.R., Stevens, C.M., Marnewick, D. \& Mortimer, G. 2018. Privately protected areas and biodiversity stewardship in South Africa: challenges and opportunities for implementation agencies. Parks 24: 4562. 